\title{
Domestic science
}

\author{
Although China is a world leader in renewable-energy technology, it is missing the chance to deploy this \\ equipment on a suitably grand scale at home.
}

T he United States' lengthy reign as the world's number-one energy consumer came to an end last year, according to the Paris-based International Energy Agency on 20 July. But the agency's revelation that China had finally taken the top slot swiftly drew denials from officials in Beijing.

China's protests are perhaps understandable given the huge international sensitivities over which nations have been - and will be responsible for most carbon emissions. But even if China is not yet number one, its population of 1.3 billion and its fast-growing economy mean that it will very soon be consuming far more energy than the United States. The only real questions are by how much will that usage grow, and how much environmental damage will it do in the process?

One fact China is not disputing is that it extended its lead in sustainable energy last year, adding 37 gigawatts of renewable capacity, nearly half of the 80 gigawatts added globally in 2009. That brought its total renewable capacity to 226 gigawatts, dwarfing the 144 gigawatts of its nearest rival, the United States (see go.nature.com/vgU3mn).

China's sustainable future has solid support from the government and the industrial and financial sectors. For example, investment in China's clean-energy companies by the financial sector hit US $\$ 33.7$ billion last year - a 53\% increase over 2008 and more than the $\$ 32.3$ billion invested in North and South America combined. And last month, Chinass National Energy Administration announced a ten-year, 5-trillionyuan (US\$738-billion) plan that will help China realize its stated target

\section{Slow progress}

\section{US cap-and-trade legislation has fallen victim to politics. But all is not lost.}

\footnotetext{
$\Lambda$ s China surges ahead with renewable energy (see above), all forward motion seems to have stalled in the US Senate. Two weeks ago, with the November elections in mind and the Republican minority in no mood to compromise, the Senate's Democratic leaders admitted that they would not have the votes this year to pass any kind of cap-and-trade system to curb carbon emissions. Instead, they opted for a scaled-back energy bill that addresses issues such as the Gulf of Mexico oil spill without doing anything to deal with global warming. As Nature went to press, it was unclear whether even that bill would pass. And with the midterm election almost certain to shift a substantial number of seats to the Republicans, who have so far been united in their opposition to what they call 'cap-and-tax', the prospects for more substantive climate legislation next year seem dim.

But behind the scenes, an informal group of energy-industry officials and environmentalists is quietly working on a proposal for compromise legislation that would impose a cap-and-trade regimen on just the
}

of 500 gigawatts of renewable-energy capacity by 2020 - nearly onethird of the nation's projected power capacity for that year.

Yet the reality of China's sustainable energy falls considerably short of the promise. For example, the installation of wind turbines continues to outstrip China's ability to hook them up to the power grid, and the sites chosen are not always where the best winds blow. The upshot is that the capacity factor, a measure of a turbine's efficiency and ultimately its profitability, is estimated to be at least $10 \%$ lower in China than in the best countries.

There are problems with solar power too. China may be the world's leading producer of photovoltaic cells, with more than $40 \%$ of the global market, but it is not even among the top five countries for installing those cells domestically. And when the Chinese government and utilities do deploy photovoltaics, they prefer big, centralized, easily managed installations, which limits a technology that is ideally suited to broad but small-scale use in places such as farms and villages. China has likewise done little to encourage the use of concentrated solar thermal energy, a low-tech but effective approach that uses lenses and mirrors to focus sunlight to run conventional steam turbines.

China's success with wind and solar manufacturing has given it good credentials in sustainable energy. But its focus on green technologies that are also immediately lucrative for export needs to give way to a more comprehensive effort to ensure that its ambitious investments in domestic green energy are as effective as possible. 